\title{
Correction to: Impact on granular bed: validation of discrete element modeling results by means of two-dimensional finite element analysis
}

\author{
Valentina Marzulli ${ }^{1}$ (D) - Luis Armando Torres Cisneros ${ }^{1} \cdot$ Annamaria di Lernia $^{2}$ (i) . \\ Christopher Robert Kit Windows-Yule ${ }^{3} \cdot$ Francesco Cafaro $^{2} \cdot$ Thorsten Pöschel $^{1}$
}

Published online: 4 May 2021

(c) The Author(s) 2021

\section{Correction to: Granular Matter (2020) 22:27 https://doi.org/10.1007/s10035-019-0988-1}

The article "Impact on granular bed: validation of discrete element modelling results by means of two-dimensional finite element analysis" written by Valentina Marzulli, Luis Armando Torres Cisneros, Annamaria di Lernia, Christopher Robert Kit Windows-Yule, Francesco Cafaro, Thorsten Pöschel was originally published Online First without Open Access. After publication in volume 22, issue 1, article 27 the author decided to opt for Open Choice and to make the article an Open Access publication. Therefore, the copyright of the article has been changed to () The Author(s) 2020 and the article is forthwith distributed under the terms of the

The original article can be found online at https://doi.org/10.1007/ s10035-019-0988-1.

Valentina Marzulli

valentina.marzulli@fau.de

Luis Armando Torres Cisneros

luis.torres@fau.de

Annamaria di Lernia

annamaria.dilernia@poliba.it

Christopher Robert Kit Windows-Yule

c.r.windows-yule@bham.ac.uk

Francesco Cafaro

francesco.cafaro@poliba.it

Thorsten Pöschel

thorsten.poeschel@fau.de

1 Institute for Multiscale Simulation, Friedrich-Alexander Universität Erlangen-Nürnberg, Cauerstrasse 3,

91058 Erlangen, Germany

2 Department of Civil, Environmental, Land, Building Engineering and Chemistry, Politecnico di Bari, Via Orabona 4, 70125 Bari, Italy

3 School of Chemical Engineering, University of Birmingham, Edgbaston, Birmingham B15 2TT, UK
Creative Commons Attribution 4.0 International License, which permits use, sharing, adaptation, distribution and reproduction in any medium or format, as long as you give appropriate credit to the original author(s) and the source, provide a link to the Creative Commons licence, and indicate if changes were made. The images or other third party material in this article are included in the article's Creative Commons licence, unless indicated otherwise in a credit line to the material. If material is not included in the article's Creative Commons licence and your intended use is not permitted by statutory regulation or exceeds the permitted use, you will need to obtain permission directly from the copyright holder. To view a copy of this licence, visit http:// creativecommons.org/licenses/by/4.0.

The original article has been corrected.

Open Access This article is licensed under a Creative Commons Attribution 4.0 International License, which permits use, sharing, adaptation, distribution and reproduction in any medium or format, as long as you give appropriate credit to the original author(s) and the source, provide a link to the Creative Commons licence, and indicate if changes were made. The images or other third party material in this article are included in the article's Creative Commons licence, unless indicated otherwise in a credit line to the material. If material is not included in the article's Creative Commons licence and your intended use is not permitted by statutory regulation or exceeds the permitted use, you will need to obtain permission directly from the copyright holder. To view a copy of this licence, visit http://creativecommons.org/licenses/by/4.0/.

Publisher's Note Springer Nature remains neutral with regard to jurisdictional claims in published maps and institutional affiliations. 